\title{
Precambrian $\mathrm{Rb}-\mathrm{Sr}$ isochron ages from the crystalline complexes of inner Forsblads Fjord, East Greenland fold belt
}

\author{
D. C. Rex, A. R. Gledhill and A. K. Higgins
}

Several collections of samples were made from crystalline units in inner Forsblads Fjord by D.C.R. and A.R.G. in 1974. Results of whole rock Rb-Sr analyses on two of these collections are presented here, and give an Archaean age for banded gneisses and a middle Proterozoic age for quartzitic metasediments. These ages confirm the occurrence of major Precambrian complexes within the East Greenland Caledonian fold belt (Hansen et al., 1973a, b, 1974; Rex \& Gledhill, 1974; Rex et al., 1976; Henriksen \& Higgins, 1976; Higgins 1976). Analyses were carried out using standard techniques (Van Breemen \& Dodson, 1972).

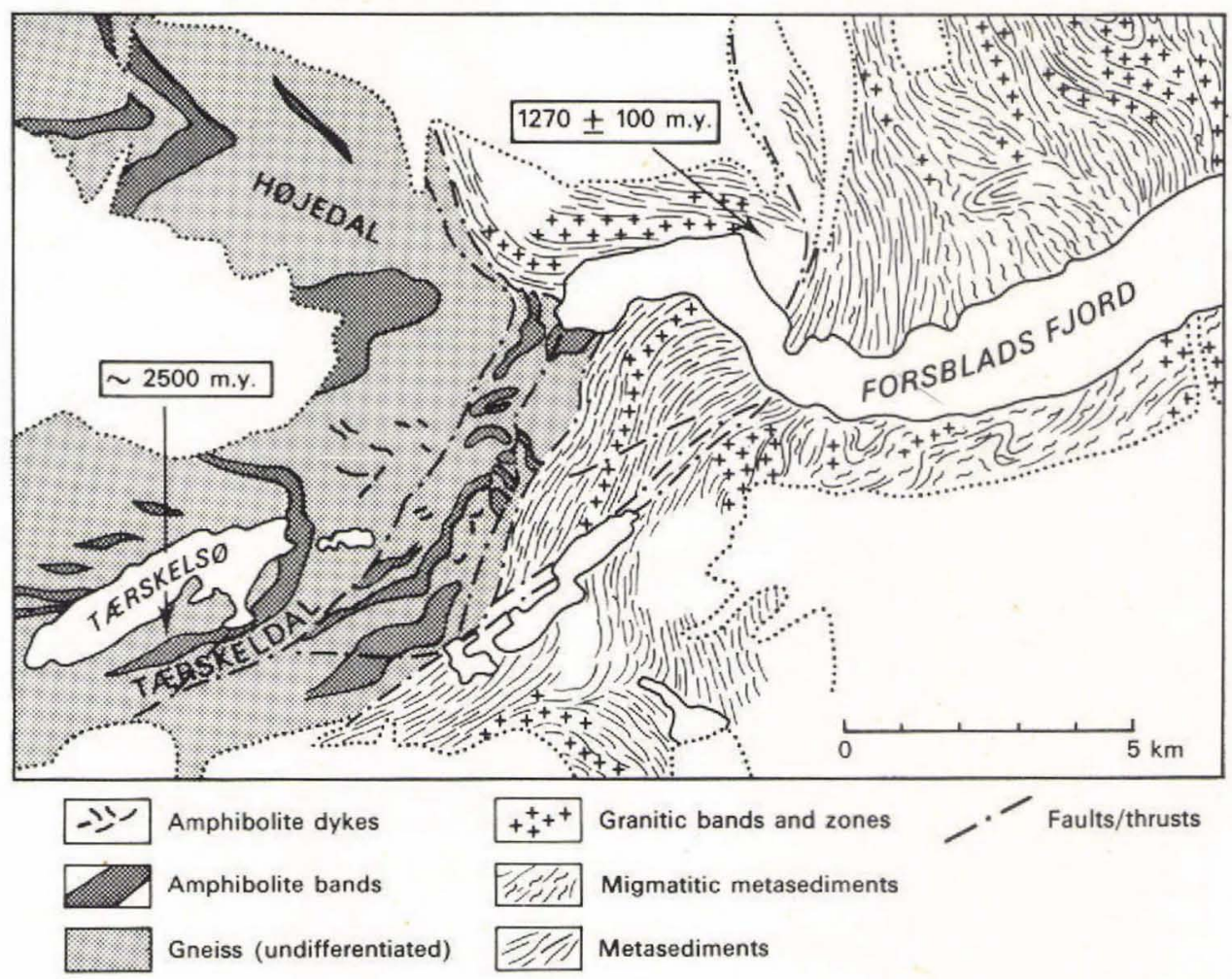

Fig. 33. Geological map of inner Forsblads Fjord, northern East Greenland, showing locations of dated sample collections. Geology modified after Haller (1958). For regional setting see fig. 31. 


\section{Tarskeldal banded gneisses}

The valley Tærskeldal rises steeply from the head of Forsblads Fjord running in a south-west direction (fig. 33). The floor and north-west side of the valley comprise banded biotite gneiss, hornblende gneiss, amphibolites and leucocratic granitic gneiss. All these rocks are cut by swarms of basic dykes, now transformed to amphibolite and folded. In line with regional interpretations of the genesis of the Caledonian fold belt, Haller $(1958,1971)$ has previously interpreted the gneisses as Caledonian migmatites and synorogenic granites, and the dykes as late Caledonian lamprophyres. Friderichsen \& Higgins (1976) consider the association of gneiss complexes and amphibolite dykes in Tærkseldal to be characteristic of Archaean basement units (see also Higgins et al., this report).

A major thrust zone follows the south-east side of Tærskeldal separating gneisses to the west from metasediments to the east. The north-east part of the valley is considerably disturbed by shear movements related to the thrust zone, and mylonites are common. The samples collected for the $\mathrm{Rb}-\mathrm{Sr}$ investigations were taken from the gneiss complex at the south-east margin of Tærskels $\varnothing$, an area relatively free from shear deformation.

The 19 samples of banded gneisses and amphibolites analysed (Table 3 ) show $\mathrm{Rb}-\mathrm{Sr}$ ratios ranging from 0.16 to 1.6 and are plotted on fig. 34 . They do not define an isochron, but scatter about a 2500 m.y. reference line. While too much significance should not be given to this figure as such, it gives a clear indication of an Archaean genesis for the gneisses, and comparisons can be made with the Flyverfjord infracrustal complex of the Scoresby Sund region which has a similar geological history. In this Archaean complex Steiger \& Henriksen (1972) have reported a zircon age of $2345 \mathrm{~m}$.y. on a foliated granite, and Hansen et al. (1973b) a K-Ar mineral age of $2525 \pm 85 \mathrm{~m}$.y. on hornblende from an amphibolite dyke. A Rb-Sr isochron of $3000 \pm 250 \mathrm{~m} . \mathrm{y}$. on gneisses from Flyverfjord (Rex \& Gledhill, 1974) is of particular interest since the 8 data points on which it is based can be plotted with the Tærskeldal analyses, clustering around the lower part of the 2500 m.y. reference line, and suggesting close geochemical similarity between the gneisses of the two regions.

The geological scatter of points of the Tærskeldal plot indicates a partial opening of the $\mathrm{Rb}-\mathrm{Sr}$ system perhaps in response to middle Proterozoic or Caledonian orogenic activity. Unpublished K-Ar mineral ages on the Tærkseldal gneisses have yielded Caledonian and mixed ages.

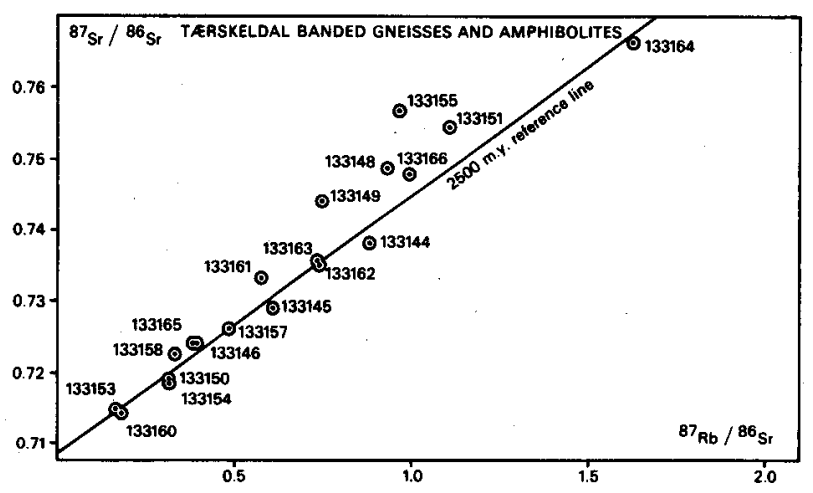

Fig. 34. Whole rock Rb-Sr plot of analytical data for Tærskeldal banded gneisses and amphibolites, and the 2500 m.y. reference line. Northern East Greenland. Decay constant ${ }^{87} \mathrm{Rb}$ $=1.39 \times 10^{-11} \mathrm{y}^{-1}$. 
Table 3. Tarskeldal banded gneisses and amphibolites, northern East Greenland

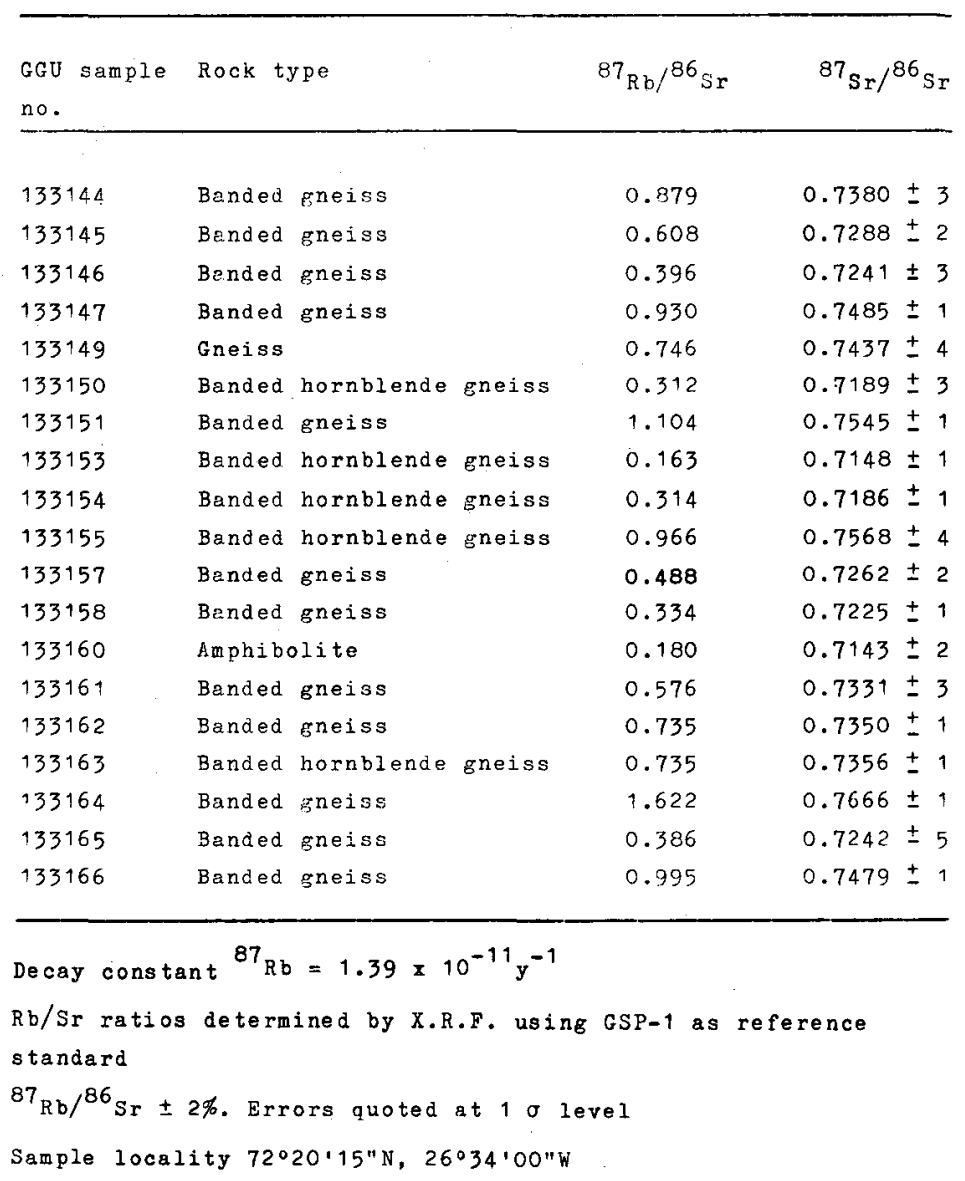

\section{Forsblads Fjord gneissic quartzites}

The greater part of Forsblads Fjord comprises migmatised sedimentary rocks and migmatitic granites. In the east an apparent transition into the Eleonore Bay Group has been described by Haller (1958) and Caby (1976), and a granite pluton cutting the Eleonore Bay Group sediments has given a $\mathrm{Rb}-\mathrm{Sr}$ isochron age of $455 \pm 5 \mathrm{~m} . \mathrm{y}$. (Rex et al., 1976). At the west end of Forsblads Fjord massive, relatively non-migmatitic, sequences of semipelitic and siliceous kyanite and sillimanite-bearing gneisses outcrop, and a collection of rather gneissic quartzites was made from the north side of the fjord (fig. 33).

Twelve samples were analysed for $\mathrm{Rb}$ and $\mathrm{Sr}$ isotopes (Table 4), and eleven of the points form an 'errochron' (fig. 35) which on the basis of McIntyre least squares cubic regression analyses yields a geological error model III age of $1270 \pm 100$ m.y. (1 $\sigma$ error). 
Table 4. Forsblads Fjord gneissic quartzites, northern East Greenland

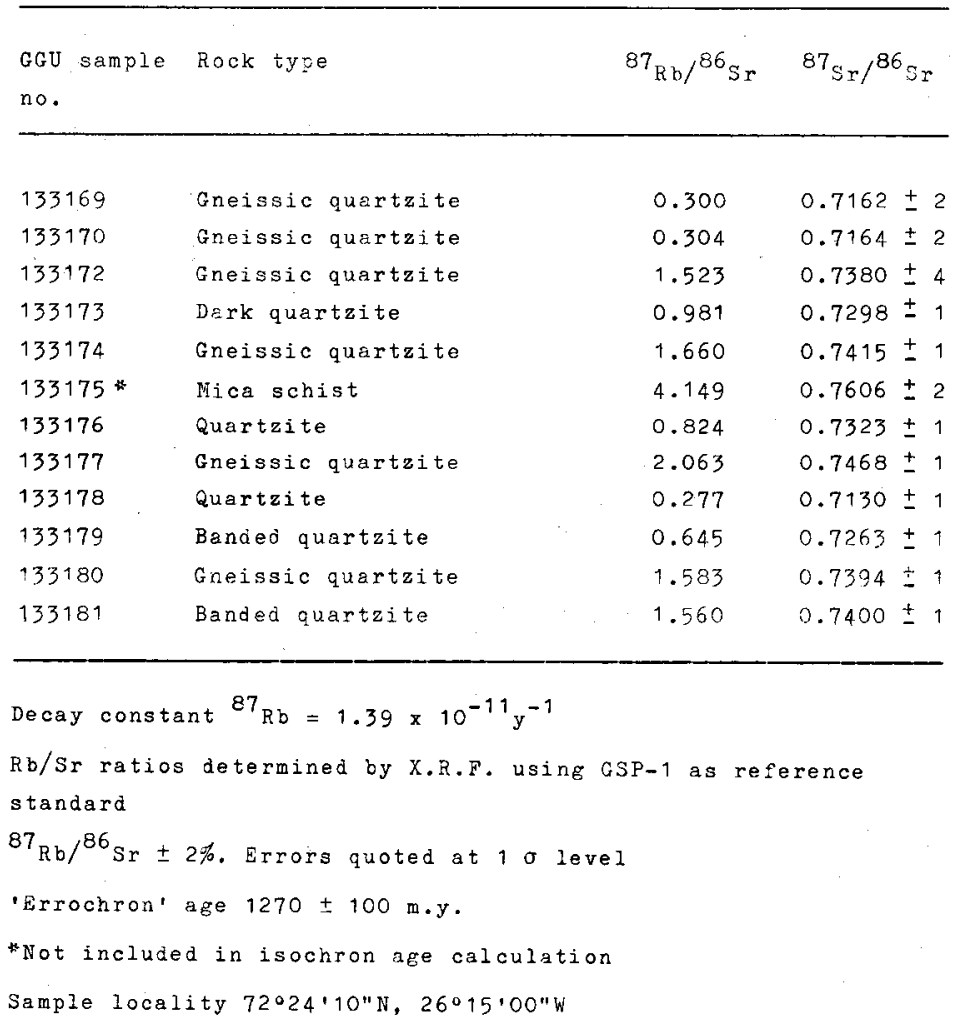

Due to the scatter of the data points the age obtained should be viewed with caution, but it clearly indicates a middle Proterozoic event, which is comparable to the $\mathrm{Rb}$-Sr isochron age of $1162 \pm 85 \mathrm{~m} . \mathrm{y}$. obtained by Hansen et al. (1974) on mica schists of the Krummedal supracrustal sequence in the southern Scoresby Sund region. This result does not conclu-

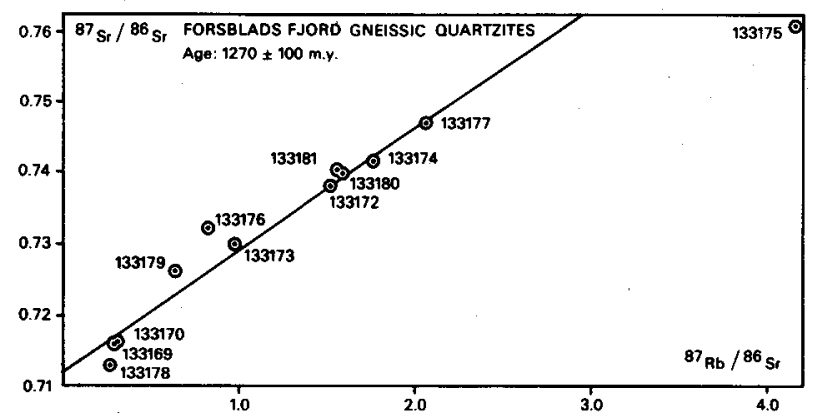

Fig. 35. Whole rock Rb-Sr plot of analytical data for Forsblads . Fjord gneissic quartzites. Sample 133175 is omitted from the isochron calculation. Northern East Greenland. Decay constant ${ }^{87} \mathrm{Rb}=1.39 \times 10^{-11} \mathrm{y}^{-1}$. 
sively show that the migmatites of the Forsblads Fjord region developed during middle Proterozoic orogenesis, though this is thought likely. However, it does indicate that somewhere in Forsblads Fjord there must exist a junction between metasediments affected by middle Proterozoic orogenesis and sediments of the late Precambrian Eleonore Bay Group affected only by the Caledonian orogeny.

\section{Acknowledgements}

The $\mathrm{Rb}$-Sr analyses were carried out in the geochronology laboratories of the University of Leeds, England, under the general direction of Prof. J. G. Ramsay and Dr. M. H. Dodson. Sample preparation and mineral separations were performed by Mr. Walter Wilkinson.

\section{References}

Caby, R. 1976: Investigations on the Lower Eleonore Bay Group in the Alpefjord region, central East Greenland. Rapp. Grønlands geol. Unders. 80, 102-106.

Friderichsen, J. D. \& Higgins, A. K. 1976: Reconnaissance work in the crystalline complexes of northern East Greenland between $72^{\circ}$ and $74^{\circ}$ N. Rapp. Grønlands geol. Unders. 80, 98-102.

Haller, J. 1958: Der "Zentrale Metamorphe Komplex" von NE-Grönland. II. Die geologische Karte der Staunings Alper und des Forsblads Fjordes. Meddr Grønland 154, 3, 153 pp.

Haller, J. 1971: Geology of the East Greenland Caledonides. 413 pp. New York: Interscience Publishers.

Hansen, B. T., Oberli, F. \& Steiger, R. H. 1973a: The geochronology of the Scoresby Sund area. 4: $\mathrm{Rb} / \mathrm{Sr}$ whole rock and mineral ages. Rapp. Gronlands geol. Unders. 58, 55-58.

Hansen, B. T. Frick, U. \& Steiger, R. H. 1973b: The geochronology of the Scoresby Sund area. 5: K/Ar mineral ages. Rapp. Grønlands geol. Unders. 58, 59-61.

Hansen, B. T., Oberli, F. \& Steiger, R. H. 1974: The geochronology of the Scoresby Sund area, central East Greenland. 6: $\mathrm{Rb} / \mathrm{Sr}$ whole rock and $\mathrm{U}-\mathrm{Pb}$ ages. Rapp. Grønlands geol. Unders. 66, 32-38.

Henriksen, N. \& Higgins, A. K. 1976: East Greenland Caledonian fold belt. In Escher, A. \& Watt, W. S. (edit.) Geology of Greenland, 182-246. Copenhagen: Geol. Surv. Greenland.

Higgins, A. K. 1976: Pre-Caledonian metamorphic complexes within the southern part of the East Greenland Caledonides. Jl geol. Soc. Lond. 132, 289-305.

Rex, D. C. \& Gledhill, A. 1974: Reconnaissance geochronology of the infracrustal rocks of Flyverfjord, Scoresby Sund, East Greenland. Bull. geol. Soc. Denmark 23, 49-54.

Rex, D. C., Gledhill, A. R. \& Higgins, A. K. 1976: Progress report on geochronological investigations in the crystalline complexes of the East Greenland Caledonian fold belt between $72^{\circ}$ and $74^{\circ} \mathrm{N}$. Rapp. Grønlands geol. Unders. 80, 127-133.

Steiger, R. H. \& Henriksen, N. 1972: The geochronology of the Scoresby Sund area. 3: Zircon ages. Rapp. Grønlands geol. Unders. 48, 109-114.

Van Breemen, O. \& Dodson, M. H. 1972: Metamorphic geochronology of the Limpopo Belt, Southern Africa. Bull. geol. Soc. Amer. 83, 2005-2018.

D.C.R. \& A.R.G., Department of Earch Sciences, University of Leeds, Leeds LS2 9JT,

U.K. 